\title{
Association of Hemoglobin C with Erythrocyte Ghosts
}

\author{
Gwen H. Reiss, Helen M. Ranney, and Nurith Shaklai, Department of \\ Medicine, University of California at San Diego, La Jolla, California 92093; \\ Department of Chemical Pathology, The Sackler School of Medicine, Tel- \\ Aviv University, Tel-Aviv, Israel
}

A B S TRACT The interaction of hemoglobin C (Hb C) with erythrocyte membranes was studied using changes in fluorescence intensity in a membraneembedded probe. The affinity of $\mathrm{Hb} \mathrm{C}$ for the membranes at $\mathrm{pH} 6.0$ and $\mathrm{pH} 6.8$ was compared to that of normal hemoglobin (Hb A). Steady-state and kinetic data were derived. The affinity of $\mathrm{Hb} \mathrm{C}$ for the erythrocyte membrane at $\mathrm{pH} 6.8$ appeared to be about five times greater than that of $\mathrm{Hb} \mathrm{A}$. The associations of $\mathrm{Hb} \mathrm{C}$ and $\mathrm{Hb} \mathrm{A}$ with the membrane were reversible to about the same extent. The cytoplasmic portions of band 3 membrane proteins were suggested to be the binding sites for both hemoglobins. The membrane binding of $\mathrm{Hb} \mathrm{C}$ at $\mathrm{pH}$ values of 6.8 to 7.0 indicates that this reaction may occur under physiological circumstances.

\section{INTRODUCTION}

Human hemoglobin $\mathrm{C}$, in which lysine replaces the normal glutamic acid at the sixth residue of the beta polypeptide chain, is encountered in the heterozygous (A/C), the homozygous $(\mathrm{C} / \mathrm{C}$ ), and the double (with $\mathrm{Hb}$ S) variant (S/C) state. Target cells on dried blood smears are frequently noted in association with $\mathrm{Hb} C$. Hemoglobin $C$ trait $(A / C)$ is without other clinical manifestations, whereas in hemoglobin $\mathrm{C}$ disease $(C / C)$, a compensated hemolytic state and splenomegaly are found. The double variant, $\mathrm{Hb} \mathrm{S} / \mathrm{C}$ disease, is clinically more severe and its frequency greater than $\mathrm{C} / \mathrm{C}$ disease, since hemoglobin $\mathrm{S}$ has a greater prevalence than $\mathrm{Hb} \mathrm{C}$ in individuals of African ancestry. Hemoglobin S/C disease is a form of sickle cell disease, generally milder than sickle cell anemia (S/S), with vasoocclusive crises, moderate anemia, frequent splenomegaly, and other complications associated with sickling. Although target cells are found in $\mathrm{Hb} \mathrm{S/C}$ disease, the dominant findings are related to sickling of the erythrocytes on deoxygenation.

Received for publication 21 August 1981 and in revised form 20 July 1982.
The sites of the amino acid substitutions of hemoglobin $\mathrm{C}$ and hemoglobin $\mathrm{S}$ are the same, the glutamic acid at beta 6 replaced by lysine and valine, respectively. The oxygen equilibria of dilute solutions of both hemoglobins are normal, including reactivity toward 2,3-diphosphoglycerate and $\mathrm{CO}_{2}$ (1). Both hemoglobins $\mathrm{C}$ and $\mathrm{S}$ are less soluble than normal hemoglobins and are known to polymerize readily (2). The solubility of $\mathrm{Hb} \mathrm{S}$ decreases on deoxygenation, resulting in intracellular fiber formation and changes in the erythrocyte shape (sickling) (3). Deoxyhemoglobin $\mathrm{C}$ is also less soluble than deoxyhemoglobin $\mathrm{A}$, but the difference is much less than that in $\mathrm{Hb} \mathrm{S}$. Abnormal physical properties $(4,5)$ are found in oxygenated as well as in deoxygenated cells containing $\mathrm{Hb} \mathrm{C}$.

In earlier studies we and others (6-8) have demonstrated binding of hemoglobin A to erythrocyte membranes. The method used in those and in the present studies utilized a fluorescent chromophore embedded in erythrocyte membranes prepared by hypotonic lysis: when hemoglobin approaches the chromophore, 12-(9-anthroyloxy)stearic acid, the fluorescence is quenched by an energy transfer mechanism. With this method, high affinity sites for hemoglobin A on the cytoplasmic surface of the membrane had been found. Hemoglobin A is bound electrostatically under conditions of low pH (5.8 to 6.5) and low ionic strength. Although electrostatic forces were found to attract hemoglobin to the cell membrane, hydrophobic forces may also play a role $(6,7)$. The binding of $\mathrm{Hb} \mathrm{A}$ is reversible, but a fraction of $\mathrm{Hb} \mathrm{S}$ may be irreversibly bound. The reversible binding of hemoglobins $A$ and $S$ is competitive with that of glyceraldehyde-3-phosphate dehydrogenase (GAPD), ${ }_{1}$ an enzyme that binds to band 3 of the erythrocyte membrane (9).

As a result of the substitution of valine for glutamic

${ }^{1}$ Abbreviations used in this paper: GAPD, glyceraldehyde-3-phosphate dehydrogenase; $5 \mathrm{~PB} 6,5 \mathrm{mM}$ sodium phosphate buffer (NaPi), pH 6.0; IO, inside-out erythrocyte vesicles; RO, right-side out vesicles. 
acid, hemoglobin $\mathrm{S}$ is more positively charged than $\mathrm{Hb} \mathrm{A}$; the subsitution of lysine in $\mathrm{Hb} \mathrm{C}$ makes this protein even more positive than $\mathrm{Hb} \mathrm{S}$. Hemoglobin $\mathrm{C}$ would be expected to exhibit greater electrostatic binding than does hemoglobin $\mathrm{A}$ or $\mathrm{S}$. The association of larger proportions of hemoglobin $\mathrm{C}$ than of $\mathrm{S}$ or $\mathrm{A}$ in membranes prepared by water lysis of erythrocytes from individuals with hemoglobins $\mathrm{S} / \mathrm{C}$ or $\mathrm{C} / \mathrm{A}$ was noted by Klipstein and Ranney (10). More recently, Natta and Muir (11) observed increased proportions of $\beta \mathrm{C}$-chains in erythrocyte ghosts prepared from $\mathrm{S} / \mathrm{C}$ patients. The present studies were designed to compare the interactions of hemoglobins $\mathrm{C}$ and $\mathrm{A}$ on addition of the purified hemoglobin to freshly prepared normal membranes in either the right-side-out or the "inside-out" state. The interaction of $\mathrm{Hb} \mathrm{C}$ with erythrocyte membranes was demonstrated at $\mathrm{pH} 6.8$ as well as at $\mathrm{pH} 6.0$, the $\mathrm{pH}$ at which earlier experiments with $\mathrm{Hb}$ A were carried out (6).

\section{METHODS}

Fluorescence measurements were performed. We used an Hitachi Perkin-Elmer MPF-44B spectrofluorimeter (Perkin-Elmer Corp., Norwalk, CT). The excitation wavelength was $360 \mathrm{~nm}$ and the emission was observed at $480 \mathrm{~nm}$ at $90^{\circ}$ to the incident beam. A filter was used to cut excitation stray light at $430 \mathrm{~nm}$ and below.

Kinetic experiments were performed on a Durrum stopped flow apparatus (Dionex Corp., Palo Alto, CA) equipped with a xenon lamp. Stray light was removed from the exciting beam with a 2-mm Corning glass 7-54 filter and the emitted light was collected through a Corning 3-73 filter (Corning Glass Co., Corning, NY).

For light absorption measurements a Beckman model DU spectrophotometer (Beckman Instruments, Inc., Fullerton, CA) and for absorption scanning a Cary 14R spectrophotometer (Cary Instrument Co., Div. Varian Associates, Palo Alto, CA) were used.

In experiments with deoxyhemoglobins, concentrated ghosts and hemoglobins were extensively deaerated by flashing oxygen-free nitrogen above the stirred solutions. Later dilutions were made with oxygen-free buffers. Small amounts of sodium dithionite (concentrations up to $0.3 \mathrm{mM}$ ) were used to minimize the ionic strength. At the conclusion of the experiments with deoxyhemoglobins, the Soret spectra of the solutions were recorded to ascertain that the hemoglobin remained deoxygenated during the experiment.

GAPD was purchased from Sigma Chemical Co., St. Louis, MO, and AS was purchased from Molecular Probes, Inc. (Plano, TX). All other chemicals were reagent grade. Hemoglobin A was prepared from fresh blood samples of normal donors. Hemoglobins $\mathrm{S}$ and $\mathrm{C}$ (from a donor with $\mathrm{S} / \mathrm{C}$ disease) were separated on DEAE-cellulose columns equilibrated with $0.05 \mathrm{M}$ Tris- $\mathrm{HCl}$ at $\mathrm{pH}$ 8.5. The hemolysate was dialyzed against the same buffer before chromatography. A discontinuous gradient of $\mathrm{pH} 8.5$ to $\mathrm{pH} 8.3$ and dismountable columns were used for chromatographic separations. The desired hemoglobin fraction was eluted with $0.05 \mathrm{M}$ Tris- $\mathrm{HCl} / 0.1 \mathrm{M} \mathrm{NaCl}$ solution, $\mathrm{pH} 7.0$, and dialyzed against the appropriate buffer immediately before use. The purity of the hemoglobin was ascertained by cellulose acetate electrophoresis at pH 8.6. Hemoglobin $\mathrm{C}$ solutions were used within several days; they were discarded if evidence of methemoglobin appeared in the absorption spectra. Solutions of GAPD were dialyzed against the buffer to be used in the experiment and centrifuged just before use to remove any precipitated material.

Ghosts were prepared by methods published previously (6) and labeled with AS in a ratio (weight) of 1:70 AS:ghost lipids. The ghosts were washed free of AS micelles and dialyzed against the appropriate buffer before use.

Inside-out membranes were prepared by a modification of the method of Steck and Kant (12). Ghosts were labeled with AS (see above), homogenized and layered on a Dextran T-70 density barrier, followed by centrifugation at 35,000 $\mathrm{rpm}$ for $2.5 \mathrm{~h}$. Sidedness of the vesicles that remained in the top band of the barrier was confirmed by the GAPD accessibility assay. The sealed inside-out ghosts were dialyzed as described above.

\section{RESULTS}

Fluorescence quenching by oxyhemoglobin: a comparison of $\mathrm{Hb} A$ and $\mathrm{Hb} C$. The interaction of $\mathrm{Hb} \mathrm{C}$ with ghosts was compared with that of $\mathrm{Hb} \mathrm{A}$. Because bound hemoglobin causes quenching of the fluorescent probe (6), the relative affinities of the two hemoglobins for the membrane could be determined by their ability to quench fluorescent-labeled ghosts.

At the same hemoglobin concentrations, $\mathrm{Hb} \mathrm{C}$ quenched more of the fluorescence intensity than did Hb A (Table I). Since the two hemoglobins have the same spectral properties, their energy-transfer parameters were assumed to be identical. Therefore, the greater quenching observed with $\mathrm{Hb} \mathrm{C}$ was attributed to its higher affinity for the erythrocyte membranes. After a 1-min incubation of hemoglobin and ghosts at low ionic strength, the ionic strength was increased by addition of $\mathrm{NaCl}: \sim 90 \%$ of the fluorescence of the $\mathrm{Hb} \mathrm{A}$-membrane preparation and of the Hb C-membrane preparation returned. Experiments were also performed using hemoglobin $\mathrm{A}_{2}$, a normal minor hemoglobin component that differs from $\mathrm{Hb} \mathrm{A}$ by ten residues in the nonalpha chain (13) and has a charge similar to $\mathrm{Hb} \mathrm{C}$. Hemoglobin $\mathrm{A}_{2}$ bound to the ghosts to the same extent as did $\mathrm{Hb} \mathrm{C}$; addition of $\mathrm{NaCl}$ restored the fluorescence of the $\mathrm{Hb} \mathrm{A_{2 }}$ solution to approximately the same level as that seen with the other hemoglobins. Since both $\mathrm{Hb}$ A and GAPD are known to bind to band 3 cytoplasmic fragments $(7,9)$, the ability of GAPD to reverse hemoglobin quenching was also tested. The competition experiments with GAPD were designed to differentiate between two possible situations: (a) increased quenching by $\mathrm{Hb} \mathrm{C}$ and $\mathrm{Hb} \mathrm{A}_{2}$ might result from their greater affinity for the band 3 sites; or $(b)$ increased quenching by $\mathrm{Hb} \mathrm{C}$ and $\mathrm{Hb} \mathrm{A}_{2}$ might be the outcome of the binding of these hemoglobins to additional membrane sites. The restoration of fluorescence by the addition of GAPD 
TABLE I

Fluorescence Changes Induced by Membrane Binding and Release of Hemoglobin

\begin{tabular}{|c|c|c|c|}
\hline \multirow[b]{2}{*}{ Sample } & \multicolumn{3}{|c|}{$\begin{array}{l}\text { Fluorescence intensity of solution } \\
\quad \text { (in arbitrary units) }\end{array}$} \\
\hline & $\mathrm{Hb} \mathrm{A}$ & $\mathrm{Hb} \mathrm{C}$ & $\mathrm{Hb} \mathrm{A_{2 }}$ \\
\hline \multicolumn{4}{|l|}{ AS-labeled membranes } \\
\hline (in 5PB6) & 100 & 100 & 100 \\
\hline Membranes and oxyhemoglobin & 73.6 & 66.8 & 66.4 \\
\hline A With $\mathrm{NaCl}: 0.01 \mathrm{M}$ & 86.3 & 69.8 & 78.6 \\
\hline $0.02 \mathrm{M}$ & 91.0 & 79.3 & 87 \\
\hline $0.03 \mathrm{M}$ & 92.1 & 85.5 & 89.5 \\
\hline $0.04 \mathrm{M}$ & & 87.8 & 90.1 \\
\hline $0.05 \mathrm{M}$ & & 89 & \\
\hline B With GAPD: $30 \mu \mathrm{M}$ & 88.2 & 74.8 & 83.9 \\
\hline $60 \mu \mathrm{M}$ & 89.1 & 83.5 & 86.2 \\
\hline $80 \mu \mathrm{M}$ & 89.5 & 86.8 & 87.3 \\
\hline $90 \mu \mathrm{M}$ & & 88 & \\
\hline $\begin{array}{l}\text { Membranes and deoxyhemoglobin } \\
\text { Membranes plus } \\
\text { deoxyhemoglobin plus } 0.05 \mathrm{M}\end{array}$ & 84 & 82 & \\
\hline $\mathrm{NaCl}$ & 98 & 98 & \\
\hline
\end{tabular}

Membranes were suspended $\left(2.7 \times 10^{10}\right.$ ghosts/liter $)$ in $5 \mathrm{mM}$ $\mathrm{NaPi}$ buffer, pH 6.0 (5PB6) and stirred continuously at $20^{\circ} \mathrm{C}$. Initial fluorescence intensity was recorded as $100 \%$ of an arbitrary scale. $\mathrm{Hb}$ was then added to yield a final concentration of $2 \times 10^{-7} \mathrm{M} \mathrm{Hb}(0.8 \mu \mathrm{M}$ heme $)$ and fluorescence measured after $1 \mathrm{~min}$. $\mathrm{NaCl}$ or GAPD was added at $1-\mathrm{min}$ intervals until maximal return of fluorescence. In the deoxy experiments, solutions of $5.4 \times 10^{10}$ ghosts/liter were used, and dithionite $(0.3$ $\mathrm{mM}$ ) was included in the 5 PB 6 to scavenge oxygen. Relative percent quenching can be calculated as $\mathbf{1 0 0}$ minus fluorescence intensity.

- Due to the nature of fluorescence, the scale used varies slightly with each membrane preparation; this fact precludes the use of statistical analyses.

shown in Table I indicated that $\mathrm{Hb} \mathrm{C}$ and $\mathrm{Hb} \mathrm{A}_{2}$ had higher affinities for band 3 than did $\mathrm{Hb} \mathrm{A}$.

When the binding of an S/C hemolysate (about 50\% $\mathrm{Hb} \mathrm{S}$ and $50 \% \mathrm{Hb} \mathrm{C)}$ with the same membrane preparation was examined, the same proportion of fluorescence was restored as that shown for $\mathrm{Hb} \mathrm{C}$ alone.

Interaction of deoxyhemoglobins with the erythrocyte membrane. Both deoxyhemoglobins $\mathrm{A}$ and $\mathrm{C}$ were bound to labeled ghosts to a lesser extent than did the liganded forms (Table I). (Deoxyhemoglobin A was shown previously [14] to exhibit a lower affinity than did oxyhemoglobin.) The affinity of deoxy $\mathrm{Hb} \mathrm{C}$ for the membranes was slightly greater than that of deoxy $\mathrm{Hb} \mathrm{A}$. While both $\mathrm{C}$ and $\mathrm{A}$ deoxyhemoglobins dissociated from the membranes to the same extent with increasing ionic strength, higher ionic strength was needed for dissociation of $\mathrm{Hb} \mathrm{C}$.

Effect of ionic strength on the dissociation of $\mathrm{Hb}$ $C$ from the erythrocyte membrane. If the attraction of hemoglobins to the erythrocyte membrane is primarily electrostatic, the dissociation of $\mathrm{Hb} \mathrm{C}$ from the membrane would require a higher ionic strength than that needed to dissociate $\mathrm{Hb} \mathrm{A}$. This assumption was tested in a set of binding experiments carried out at $\mathrm{pH}$ 6.0, using the same concentrations of ghosts and of hemoglobins. The data shown in Fig. 1 indicated that even with the low concentration of hemoglobins used in these experiments, higher ionic strength was needed to release $\mathrm{Hb} \mathrm{C}$ from the membrane than that required for a similar effect with $\mathrm{Hb} \mathrm{A}$.

Dependency of $\mathrm{Hb} C$ interaction with the membrane on $\mathrm{pH}$. The ability of $\mathrm{Hb} \mathrm{C}$ to interact with the erythrocyte membrane at $\mathrm{pH}$ values $>6.0$, and therefore, closer to physiological hydrogen ion concentraton, was followed in a series of experiments. The same concentraton of $\mathrm{Hb} \mathrm{C}$ was added to membranes that had been diluted to identical concentrations with buffers at various $\mathrm{pH}$ values. The results were compared with the findings for binding of $\mathrm{Hb} \mathrm{A}$ in this $\mathrm{pH}$ range using the same ghost preparation. From Fig. 2, it is evident that although the affinity of $\mathrm{Hb} \mathrm{A}$ at $\mathrm{pH}$ 7.0 was only $10 \%$ of that observed at $\mathrm{pH} 6.0$, the affinity of $\mathrm{Hb} \mathrm{C}$ at $\mathrm{pH} 7.0$ was still $75 \%$ of the maximal (pH 6.0) value.

Calculation of the binding constant of $\mathrm{Hb} C$ and of $\mathrm{Hb} \mathrm{A}$ to the erythrocyte membrane at $\mathrm{pH} 6.8$. Binding constants for the two proteins at $\mathrm{pH} 6.8$ were determined essentially as described previously (15).

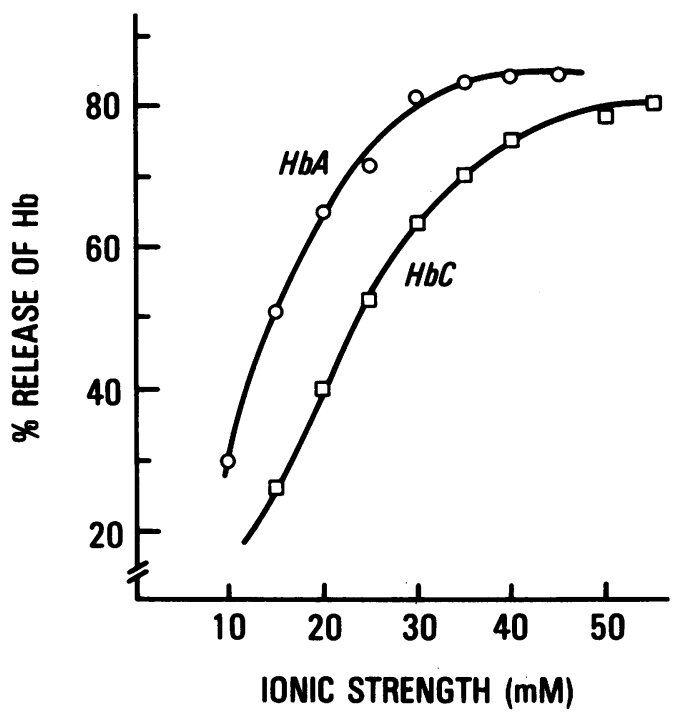

Figure 1 Effect of ionic strength on the dissociation of $\mathrm{Hb} \mathrm{C} \mathrm{( \square )} \mathrm{and} \mathrm{Hb} \mathrm{A} \mathrm{(O)} \mathrm{from} \mathrm{erythrocyte} \mathrm{membranes.} \mathrm{A}$ final concentration of $2 \times 10^{-7} \mathrm{M} \mathrm{Hb}$ tetramer was added to unsealed membranes $\left(2.7 \times 10^{10}\right.$ ghosts/liter in 5PB6). The various ionic strengths were achieved by serial additions of $\mathrm{NaCl}$ to the hemoglobin/ghost solutions. 


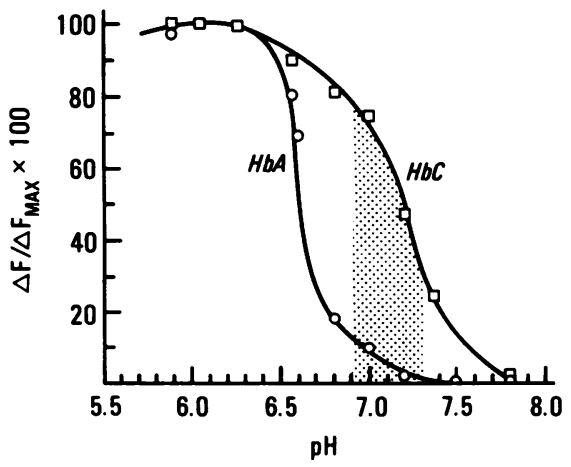

Figure $2 \mathrm{pH}$ dependency of the reactions of $\mathrm{Hbs} \mathrm{C}$ and $\mathrm{A}$ with erythrocyte ghosts. Hemoglobin and membrane concentrations as in Fig. 1, buffered with 5PB. The fluorescence intensity (in percent from the maximal value at pH 5.8) is plotted on the ordinate. Hb C: $\square$; $\mathrm{Hb} \mathrm{A:} \mathrm{O.} \mathrm{The}$ shaded area indicates physiologic intracellular $\mathrm{pH}$ values for erythrocytes containing $\mathrm{Hb} \mathrm{A}$ or $\mathrm{Hb} \mathrm{C}(16,17)$.

Stoichiometric binding of hemoglobins to membranes was followed using high ghost concentrations $\left(10^{11}\right.$ ghosts/liter). The results are shown in Fig. 3A. In another set of experiments (Fig. 3B), the ghost concentrations were lower $\left(10^{9}\right.$ ghosts/liter), and equilibrium measurements of the binding were taken. Data are depicted in Figs. $3 \mathrm{~A}$ and $\mathrm{B}$ as fluorescent quenching plotted against total hemoglobin concentration. The Hill plots shown in Figs. 3C and D were derived from the amount of hemoglobin bound in the equilibrium experiments (computed from the values given in Figs.

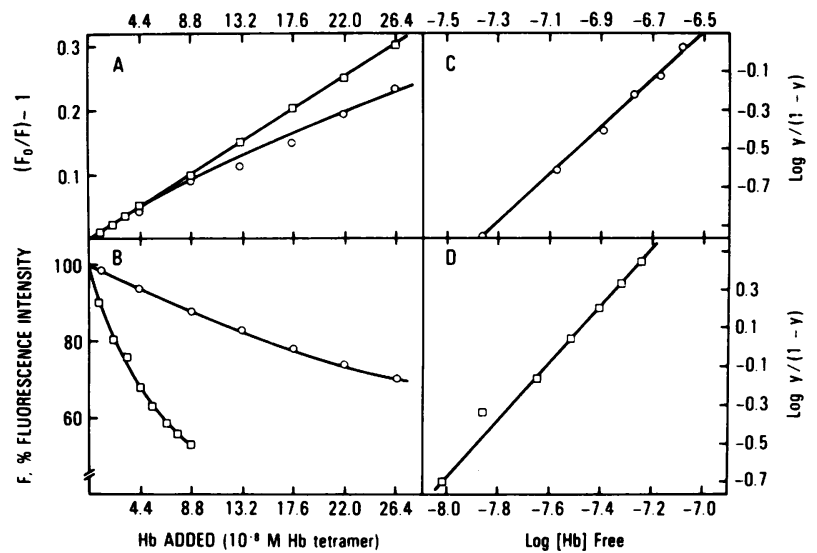

Figure 3 Affinity of $\mathrm{Hb} \mathrm{C} \mathrm{( \square )} \mathrm{and} \mathrm{Hb} \mathrm{A} \mathrm{(O)} \mathrm{in} \mathrm{5PB6.8.}$ (A) Titration under stoichiometric conditions. Concentration of membranes was $10^{11}$ ghosts/liter. Each unit on the abscissa represents $4.4 \times 10^{-8} \mathrm{M} \mathrm{Hb}$ tetramer. (B) Titration under equilibrium conditions $\left(10^{9}\right.$ ghosts/liter). Units as in $A$. (C) A Hill plot of the data calculated from $\mathrm{A}$ and $\mathrm{B}$ for $\mathrm{Hb} \mathrm{A}$. $Y$, average fraction of membrane sites saturated with hemoglobin. (D) A Hill plot of the data calculated from $A$ and $\mathrm{B}$ for $\mathrm{Hb} \mathrm{C}$. For details see reference 6.
$3 \mathrm{~A}$ and $\mathrm{B})$. The binding constants calculated from the Hill plots are $\mathrm{K}=3.7 \times 10^{6} \mathrm{M}^{-1}$ for $\mathrm{Hb} \mathrm{A}$, and $\mathrm{K}=35.0 \times 10^{6} \mathrm{M}^{-1}$ for $\mathrm{Hb} \mathrm{C}$.

Kinetics of hemoglobin $C$ binding to the cell membrane. A comparison of hemoglobins $A$ and $C$. Kinetic experiments used stopped-flow fluorescence quenching as previously described (15). Association of hemoglobin with the cell membrane was found to be independent of concentrations of ghosts. Nevertheless, since the changes in fluorescence intensity related to settling can be avoided when low concentrations of membranes are used, the experiments were performed with $10^{9}-10^{10}$ ghosts/liter. Because apparent first order rates depended in a linear manner on hemoglobin concentration (15), the rate constants of the "on" reactions were calculated by dividing the apparent first order constants by the final hemoglobin concentration. In Fig. 4 (left panel) the binding rates of $\mathrm{Hb} \mathrm{A}$ and $\mathrm{Hb} \mathrm{C}$, both in the oxy state at $\mathrm{pH} \mathrm{6.8,} \mathrm{are} \mathrm{compared;}$ $\mathrm{Hb} \mathrm{C}$ reacted faster than did $\mathrm{Hb} \mathrm{A}$. It is important to note that if the reaction with the membrane sites were limited by unstirred layers, all hemoglobins at the same concentration would have shown the same reaction rates. The fact that $\mathrm{Hb} \mathrm{C}$ reacted faster than $\mathrm{Hb} \mathrm{A}$ at the same concentration indicated that the membrane sites were close enough to the solution bulk to avoid unstirred layers. First order semilogarithmic plots of the reactions were resolved into two rate constants as previously described (9). The fast "on" reaction rate constants calculated were: $k=0.55 \pm 0.1$ $\times 10^{6} \mathrm{~s}^{-1} \mathrm{M}^{-1}$ for hemoglobin A and $1.0 \pm 0.2 \times 10^{6} \mathrm{~s}^{-1}$ $\mathrm{M}^{-1}$ for hemoglobin $\mathrm{C}$.

In Fig. 4 (right panel) the dissociation rates of $\mathrm{Hb} \mathrm{A}$ and $\mathrm{Hb} \mathrm{C}$ from the membrane at $\mathrm{pH} 6.8$ are demonstrated. These experiments were performed using excess GAPD to compete with hemoglobin for the

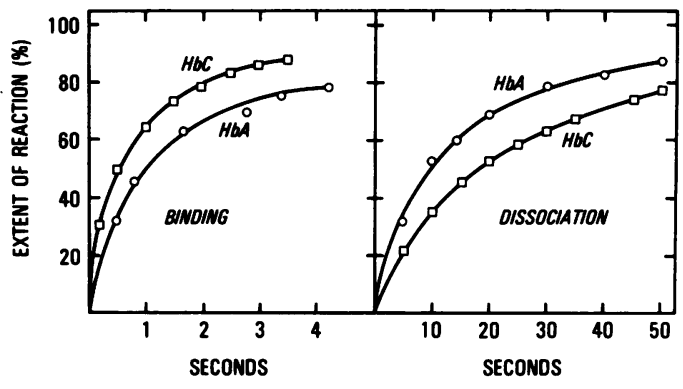

Figure 4 Time dependency of the association and dissociation of erythrocyte membranes and oxyhemoglobins $\mathrm{C}$

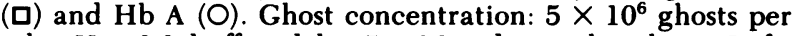
$\mathrm{ml}, \mathrm{pH}=6.8$ buffered by $5 \mathrm{mM}$ sodium phosphate. Left: Binding reaction with $2.25 \times 10^{-8} \mathrm{M} \mathrm{Hb}$ tetramer $(\mathrm{Hb} \mathrm{A}$ or Hb C). Right: Dissociation reaction. Ghosts were saturated with hemoglobin and the dissociation was achieved by mixing the hemoglobin-bound ghosts with $4.5 \mu \mathrm{M}$ GAPD. 
membrane sites (7). The time course of the reaction was analyzed assuming two different rate constants for the high and low affinity sites; the lower dissociation rate is assumed to demonstrate the high affinity sites (15). The rate constants of the "off" reactions calculated were: $0.08 \pm 0.02 \mathrm{~s}^{-1}$ and $0.03 \pm 0.01 \mathrm{~s}^{-1}$ for $\mathrm{Hb} \mathrm{A}$ and $\mathrm{Hb} \mathrm{C}$, respectively.

The binding constants of $\mathrm{Hb} \mathrm{C}$ and $\mathrm{Hb} \mathrm{A}$ at $20^{\circ} \mathrm{C}$, pH 6.8 were calculated from the rate constants of the "on" and "off" reactions as follows:

as

$$
{ }^{\mathrm{k}} \mathrm{Hb} \mathrm{C}={ }^{\mathrm{k}} \text { on } /{ }^{\mathrm{k}} \text { off }=1.0 \times 10^{6} / 0.03=33.0 \times 10^{6} \mathrm{M}^{-1},
$$

and

${ }^{\mathrm{k}} \mathrm{Hb} \mathrm{A}={ }^{\mathrm{k}}$ on $/{ }^{\mathrm{k}}$ off $=0.5 \times 10^{6} / 0.08=6.25 \times 10^{6} \mathrm{M}^{-1}$.

There was satisfactory agreement between the individual rate constants above and the direct measurement of the equilibrium constants $\left({ }^{\mathrm{K}} \mathrm{Hb} \mathrm{C}=\mathbf{3 5 . 0}\right.$ $\times 10^{6} \mathrm{M}^{-1},{ }^{\mathrm{k}} \mathrm{Hb} \mathrm{A}=3.7 \times 10^{6} \mathrm{M}^{-1}$ ).

TABLE II

IO Membranes: pH-dependent Binding and Dissociation of Hemoglobins $A$ and $C$

\begin{tabular}{|c|c|c|}
\hline \multirow{2}{*}{$\begin{array}{l}\text { IO membranes and } \\
\text { oxyhemoglobin }\end{array}$} & \multicolumn{2}{|c|}{$\begin{array}{l}\text { Fluorescence intensity } \\
(\% \text { arbitrary scale })^{\bullet}\end{array}$} \\
\hline & Hb A & Hb C \\
\hline pH 5.5 & 51.5 & 47.8 \\
\hline A) $+\mathrm{NaCl}: 0.03 \mathrm{M}$ & 76.6 & 72.5 \\
\hline $0.05 \mathrm{M}$ & 76.6 & 73.7 \\
\hline $\mathrm{pH} 6.0$ & 52.2 & 49.1 \\
\hline A) $+\mathrm{NaCl}: 0.03 \mathrm{M}$ & 83.8 & 81.2 \\
\hline $0.04 \mathrm{M}$ & 83.8 & 82.7 \\
\hline $\mathrm{pH} 6.4$ & 57.8 & 51.6 \\
\hline A) $+\mathrm{NaCl}: 0.02 \mathrm{M}$ & 88.7 & 85.4 \\
\hline $0.03 \mathrm{M}$ & 88.7 & 86.1 \\
\hline $\mathrm{pH} 6.8$ & 81.3 & 65.8 \\
\hline A) $+\mathrm{NaCl}: 0.01 \mathrm{M}$ & 90.9 & 88 \\
\hline $0.02 \mathrm{M}$ & 90.9 & 89 \\
\hline B) +GAPD: $30 \mu \mathrm{M}$ & 89.2 & 79.9 \\
\hline $60 \mu \mathrm{M}$ & 89.2 & 84 \\
\hline $\mathrm{pH} 7.0$ & 91.1 & 80.5 \\
\hline A) $+\mathrm{NaCl}: 0.01 \mathrm{M}$ & 91.1 & 90 \\
\hline $\mathrm{pH} 7.2$ & 92.5 & 90 \\
\hline A) $+\mathrm{NaCl}: 0.01 \mathrm{M}$ & 92.5 & 90.8 \\
\hline
\end{tabular}

- Initial fluorescence of the IO vesicles (21.2 $\mu \mathrm{g}$ membrane protein/ $\mathrm{ml}$ in 5 PB6) was recorded as $100 \%$ of an arbitrary scale (scale differs for each membrane preparation). $2 \times 10^{-7} \mathrm{M} \mathrm{Hb}$ tetramer (final concentration) was added to each sample. Concentrations of $\mathrm{NaCl}$ and GAPD given above yielded maximal return of fluorescence. Measurements were made after 1 -min incubations.
TABLE III

Effects of Buffer Ionic Strength and Hemoglobin Concentration on Affinities of Hemoglobins A and C to IO Vesicles

\begin{tabular}{|c|c|c|}
\hline \multirow{2}{*}{$\frac{\text { Sample }}{\text { Buffer: } \mathrm{mM} \mathrm{NaPi}, \mathrm{pH}}$} & \multicolumn{2}{|c|}{$\begin{array}{l}\text { Fluorescence intensity } \\
(\% \text { of an arbitrary scale })^{\circ}\end{array}$} \\
\hline & $2 \times 10^{-7} \mathrm{M} \mathrm{Hb} \mathrm{A}$ & $2 \times 10^{-7} \mathrm{M} \mathrm{Hb} \mathrm{C}$ \\
\hline 2.5PB6.8 & 65.2 & 57.2 \\
\hline 5PB6.8 & 88 & 74 \\
\hline 10PB6.8 & 93 & 91 \\
\hline $\begin{array}{l}\text { Concentration of } \mathrm{Hb} \\
\text { tetramer (in } 5 \mathrm{~PB} 6.8 \text { ) }\end{array}$ & Hb A & $\mathrm{Hb} \mathrm{C}$ \\
\hline $1 \times 10^{-7} \mathrm{M} \mathrm{Hb}$ & 91.5 & 79 \\
\hline $2 \times 10^{-7} \mathrm{M} \mathrm{Hb}$ & 88 & 74 \\
\hline $4 \times 10^{-7} \mathrm{M} \mathrm{Hb}$ & 77.2 & 62.7 \\
\hline
\end{tabular}

- Scale based on initial fluorescence of the IO vesicles $(21.2 \mu \mathrm{g}$ membrane protein $/ \mathrm{ml}$ ) given as $100 \%$. Readings were taken after l-min incubations of the hemoglobins with the vesicles.

The kinetics of hemoglobins $\mathrm{C}$ and $\mathrm{A}$ in the deoxy state followed the same trend as in the oxy state: the rate of $\mathrm{Hb} \mathrm{C}$ was double that of $\mathrm{Hb} \mathrm{A}$ for the on reaction, and was approximately one-half the $\mathrm{Hb} \mathrm{A}$ value for the off reaction.

The interaction of inside-out membranes with hemoglobins. To verify the cytoplasmic site of the membrane binding of hemoglobin, experiments were done using inside-out (IO) vesicles. When $\mathrm{Hb} \mathrm{A}, \mathrm{C}$, or $\mathrm{S}$ was added to AS-labeled IO ghosts a much greater quenching of fluorescence was observed than was seen with unsealed right-side-out (RO) ghosts: in IO ghosts the concentration of membranes which yielded the same degree of fluorescence quenching was about onefourth the concentration of RO ghosts. All three hemoglobins demonstrated a greater affinity for the IO than for the RO. These observations can probably be attributed to the increased number of binding sites available on the IO vesicles. Kliman and Steck (16) have reported that the association rate constant for GAPD binding is slightly greater for IO vesicles than for saponin-treated ghosts. Tables II and III show that the binding and dissociation of hemoglobins $\mathrm{A}$ and $\mathrm{C}$ with the IO membranes parallel that seen with the RO. The qualitative effects of $\mathrm{NaCl}, \mathrm{GAPD}$ and changes in $\mathrm{pH}$ were all in agreement with the data from the experiments using RO membranes.

Effects of ionic strength and concentration of hemoglobin on binding. The methods of fluorescence spectroscopy used in these studies permit observations only on dilute solutions of hemoglobin $\left(2 \times 10^{-7} \mathrm{Hb}\right.$ tetramer). The binding is maximized in buffers of low ionic strength, e.g. $5 \mathrm{mM}$. Experiments to examine the 
effects of increasing either the ionic strength or the concentration of hemoglobin were carried out with inside-out ghosts at pH 6.8 (Table III). At constant hemoglobin concentrations, binding decreased with increasing ionic strength of the buffer. Increasing the concentration of hemoglobin led to enhanced binding, with more salt required for release of bound hemoglobin from the membranes.

\section{DISCUSSION}

Physiological $\mathrm{pH}$ values for erythrocytes have been reported in the range of 7.0-7.3 (16). In $\mathrm{Hb} \mathrm{C} / \mathrm{C}$ erythrocytes, $\mathrm{pH}$ vaues were $\sim 0.1 \mathrm{pH}$ units lower than normal (18). Our $\mathrm{pH}$ dependency binding experiments (Fig. 2 and Table II) suggest that under physiological conditions more $\mathrm{Hb} \mathrm{C}$ than $\mathrm{Hb} \mathrm{A}$ would be attached to the membrane. We chose to calculate hemoglobin binding affinities at $\mathrm{pH} \mathrm{6.8,} \mathrm{because} \mathrm{binding} \mathrm{of} \mathrm{Hb} \mathrm{A}$ at the low concentrations required for fluorescence measurements can still be shown at this near physiologic $\mathrm{pH}$ value (6). Quantitative steady-state values analyzed in Fig. 3 show that the binding constant of $\mathrm{Hb} \mathrm{C}$ at $\mathrm{pH} 6.8\left(35 \times 10^{6} \mathrm{M}^{-1}\right)$ was slightly lower than the binding constant for $\mathrm{Hb} \mathrm{A}$ at $\mathrm{pH} 6.0$, calculated previously to be $80 \times 10^{6} \mathrm{M}^{-1}(6)$.

That the binding of hemoglobin can be best demonstrated in solutions of low ionic strength appears to reflect, at least in part, the low concentrations of hemoglobin that must be used in these studies. In the intact human erythrocyte, the concentration of hemoglobin is 25,000 times that used in these studies, while the ionic strength is 30 times greater. The electrostatic nature of the binding was confirmed by the increased binding observed with increased hemoglobin concentration and with decreasing ionic strength. Increased binding in solutions of low ionic strength has also been found with GAPD; Kliman and Steck (16) suggest that in the case of GAPD some ions exert ligand effects in addition to salt effects.

Kinetic experiments were performed to analyze the mechanism responsible for the differences between hemoglobins $\mathrm{A}$ and $\mathrm{C}$. The data show that the rate of the combination reaction of $\mathrm{Hb} \mathrm{C}$ with the erythrocyte membrane is higher than that calculated for $\mathrm{Hb} \mathrm{A}$ at the same $\mathrm{pH}$. The on rates for each hemoglobin appear to depend on $\mathrm{pH}$, as shown by the comparison of rate constants in this study for $\mathrm{Hb} \mathrm{A}$ at $\mathrm{pH} 6.8$, and the earlier results at $\mathrm{pH} 6.0$ (15). The off rates calculated at $\mathrm{pH} 6.8$ indicate that $\mathrm{Hb} \mathrm{C}$ dissociates from the membrane at a somewhat lower rate than does $\mathrm{Hb} \mathrm{A}$. The differences in both on and off kinetic rate constants for the two hemoglobins account for the differences between their affinity constants as determined by the steady-state data. Thus, the binding constant for $\mathrm{Hb} \mathrm{C}$ as calculated from the rate constant is the same (within experimental error) as that calculated from the equilibrium values. The high affinity of $\mathrm{Hb} \mathrm{C}$ for the erythrocyte membranes is comparable to the affinities reported for the glycolytic enzymes GAPD and aldolase $(9,19)$. Hemoglobin C, normally present in the cell at much higher concentrations than these enzymes, might impair their binding to the membrane. Experiments in this and previous work have shown that the affinities of hemoglobin $\mathrm{C}$ and of $\mathrm{S}$ for the membrane exceed that of $\mathrm{Hb} A$ (20). Hemoglobin $\mathrm{A}_{2}$, which has a positive charge similar to $\mathrm{Hb} \mathrm{C}$, also bound to normal ghosts to a slightly greater extent than $\operatorname{did} \mathrm{Hb}$ A. As shown in Table I, when the ionic strength was sufficiently elevated, similar proportions of $\mathrm{Hb} \mathrm{C}$, $\mathrm{Hb} \mathrm{A}$, and $\mathrm{Hb} \mathrm{A}_{2}$ dissociated from the membrane. The data indicate that the binding of hemoglobins $C$ and $\mathrm{A}_{2}$ closely resemble that of $\mathrm{Hb} \mathrm{A}$. In each the interaction was electrostatic and addition of GAPD restored the fluorescence intensity to about the same degree. The competition with GAPD suggests that hemoglobins $\mathrm{C}$ and $\mathrm{A}_{2}$ (like $\mathrm{Hb} \mathrm{A}$ ) are bound to band 3 cytoplasmic fragments, which are considered to be highaffinity and reversible binding sites. (There are, in contrast, lower affinity and less reversible sites such as phosphatidyl serine [7, 21].) It should be noted, however, that small amounts of $\mathrm{NaCl}(0.01-0.03 \mathrm{M}$, final concentration) released a greater proportion of $\mathrm{Hb} \mathrm{A}$ or $\mathrm{Hb} \mathrm{A}_{2}$ than of $\mathrm{Hb} \mathrm{C}$ or $\mathrm{Hb} \mathrm{S}$ from the membrane. Even large amounts of $\mathrm{NaCl}$ or GAPD may not completely disengage all the $\mathrm{Hb} \mathrm{S}$ bound to the ghosts (20). The apparent differences in the dissociation of hemoglobins $\mathrm{A}_{2}, \mathrm{C}$ and $\mathrm{S}$ from the ghosts imply that the net charge of the molecule may not be the only factor affecting the interaction of a hemoglobin with the membrane.

Deoxy $\mathrm{Hb} \mathrm{C}$ is also less soluble than deoxy $\mathrm{Hb} \mathrm{A}$, and intracellular aggregates have been observed in the variant (2). Fabry et al. (22) recently reported that erythrocytes from splenectomized $\mathrm{Hb} \mathrm{C/C}$ patients had a greater viscosity when deoxygenated than when in the oxy state. The difference in viscosity was smaller in cells from nonsplenectomized $\mathrm{Hb} \mathrm{C} / \mathrm{C}$ subjects; this suggests an effect of intracellular aggregates of $\mathrm{Hb} \mathrm{C}$ on erythrocyte membranes that is ameliorated by passage of the erythrocytes through the spleen. In the present studies a reversible electrostatic binding of $\mathrm{Hb} \mathrm{C}$ to erythrocyte ghosts appeared to occur under physiologic conditions. The greater binding of $\mathrm{Hb} \mathrm{C}$ than of $\mathrm{Hb} \mathrm{S}$ might protect the membrane from $\mathrm{Hb} \mathrm{S}$ in cells containing both hemoglobins. ${ }^{2}$

\footnotetext{
${ }^{2}$ Since this paper was submitted for publication, Eisinger et al. (23) have provided evidence for binding of normal hemoglobin to the membrane in intact erythrocytes.
} 


\section{ACKNOWLEDGMENTS}

The authors are deeply indepted to Dr. Vijay Sharma for his advice and help with the kinetic experiments, and to Drs. Helen M. Anderson and Elizabeth Danish for kindly supplying us with blood samples.

This work was supported in part by United States-Israel Binational Science Foundation grant 1879/79 and grants AM17348 and AM18781 from the National Institutes of Health.

\section{REFERENCES}

1. Bunn, H. F. 1972. The interaction of sickle hemoglobin with DPG, $\mathrm{CO}_{2}$ and with other hemoglobins: formation of asymmetrical ligands. Hemoglobin and Red Cell Structure and Function. Adv. Exp. Med. Biol. 28: 4146.

2. Charache, S., C. L. Conley, D. F. Waugh, R. J. Ugoretz, and J. R. Spurell. 1967. Pathogenesis of hemolytic anemia in homozygous hemoglobin C disease. J. Clin. Invest. 46: 1795-1811.

3. Bunn, H. F., B. G. Forget, and H. M. Ranney. 1977. Sickle cell anemia and related disorders. In Human Hemoglobins. W. B. Saunders Company, Philadelphia. 228-280.

4. Jandl, J. H., R. L. Simmons, and W. B. Castle. 1961. Red cell filtration and the pathogenesis of certain hemolytic anemias. Blood. 18: 133-148.

5. Teitel, P. 1965. Disk-sphere transformation and plasticity of alteration of red cells. Nature (Lond.). 206: 409410.

6. Shaklai, N., J. Yguerabide, and H. M. Ranney. 1977. Interaction of hemoglobin with red blood cell membranes as shown by a fluorescent chromophore. Biochemistry. 16: 5585-5592.

7. Shaklai, N., J. Yguerabide, and H. M. Ranney. 1977. Classification and localization of hemoglobin binding sites on the red blood cell membrane. Biochemistry. 16: 5593-5597.

8. Fischer, S., R. Nagel, R. M. Bookchin, E. F. Roth, and I. Teller-Nagel. 1975. The binding of hemoglobin to membranes of normal and sickle erythrocytes. Biochim. Biophys. Acta. 375: 422-433.

9. Kant, J. A., and T. L. Steck. 1973. Specificity in the association of glyceraldehyde-3-phosphate dehydroge- nase with isolated human erythrocyte membranes. $J$. Biol. Chem. 248: 8457-8464.

10. Klipstein, F. A., and H. M. Ranney. 1960. Electrophoretic components of the hemoglobin of red cell membranes. J. Clin. Invest. 39: 1894-1899.

11. Natta, C., and M. Muir. 1980. Preferential binding of beta $C$ relative to beta $S$ globin. Hemoglobin. 4: 157163.

12. Steck, T. L., and J. A. Kant. 1974. Preparation of impermeable ghosts and inside-out vesicles from human erythrocyte membranes. Methods Enzymol. 31: 172180.

13. Bunn, H. F., F. G. Forget, and H. M. Ranney. 1977. Hemoglobin structure. In Human Hemoglobins. W. B. Saunders Company, Philadelphia. 17-18.

14. Shaklai, N., and H. Abraham. 1980. Interaction of deoxyhemoglobin with the red cell membranes. Biochem. Biophys. Res. Commun. 95: 1105-1112.

15. Shaklai, N., and V. S. Sharma. 1980. Kinetic study of the interaction of oxy and deoxyhemoglobins with the erythrocyte membrane. Proc. Natl. Acad. Sci. USA. 77: 7147-7151.

16. Kliman, H. J., and T. L. Steck. 1980. Association of glyceraldehyde-3-phosphate dehydrogenase with the human red cell membrane. J. Biol. Chem. 255: 6314-6321.

17. Roos, A., and W. F. Boron. 1981. Intracellular pH. Physiol. Rev. 61: 269-435.

18. Murphy, J. R. 1976. Hemoglobin CC erythrocytes: decreased intracellular and decreased $\mathrm{O}_{2}$-affinity anemia. Semin. Hematol. 13: 177-180.

19. Strapezon, E., and T. L. Steck. 1976. Binding of rabbit muscle aldolase to band 3 , the predominant polypeptide of the human erythrocyte membrane. Biochemistry. 15: 1421-1424.

20. Shaklai, N., and H. M. Ranney. 1981. Interaction of sickle cell hemoglobin with erythrocyte membranes. Proc. Natl. Acad. Sci. USA. 78: 65-68.

21. Shaklai, N., and H. M. Ranney. 1978. Interaction of hemoglobin with membrane lipids: A source of pathological phenomena. Isr. J. Med. Sci. 14: 1152-1156.

22. Fabry, M. E., D. K. Kaul, C. Raventos, S. Baez, R. Rieder, and R. L. Nagel. 1981. Some aspects of the pathophysiology of homozygous Hb CC erythrocytes. J. Clin. Invest. 67: 1284-1291.

23. Eisinger, J., J. Flores, and J. M. Salhany. 1982. Association of cytosol hemoglobin with the membrane in intact erythrocytes. Proc. Natl. Acad. Sci. USA. 79: 408-412. 